\title{
Single Proton Hit Facility at the IFJ PAN in Cracow
}

\author{
W. Polak, J. Lekki, O. Veselov, Z. Stachura \\ AND J. STYCZEŃ \\ The Henryk Niewodniczański Institute of Nuclear Physics \\ Polish Academy of Sciences (IFJ PAN) \\ Radzikowskiego 152, 31-342 Kraków, Poland
}

This work presents the final development stage and optimization results of the single proton hit facility in Cracow. The setup parameters: proton beam energy $2 \mathrm{MeV}$, hit resolution $30 \mu \mathrm{m}$, intensity $\approx 1000$ proton/s, proton registration efficiency $100 \%$, blanking efficiency $99.8 \%$. On-line observation allows targeting cells inside a Petri dish mounted at a $3 \mathrm{D}$ precise moving stage. To target a particular cell a semiautomatic cell visualization and recognition system is used.

PACS numbers: 87.50.Gi, 87.50.--a

\section{Introduction}

The Cracow single proton-single cell hit facility is designed to measure low dose (below 0.25 Gy) radiation influence on living cells. Low dose effects are still not fully understood, despite recent experiments of many laboratories [1-4]. Precise knowledge about the number and exact position of irradiated cells allows also investigating a non-targeted effect, such as the so-called "bystander effect" [5]. This term relates to a situation, when after irradiating a particular cell its neighbours (not necessarily the closest) also show increased damage.

\section{The setup}

Our single proton hit (SPH) facility is based on up to $2.5 \mathrm{MeV}$ proton microprobe, currently characterized by a beam spot size of $10 \times 10 \mu \mathrm{m}^{2}[6,7]$. A focused beam, after passing through a silicon nitride $\left(\mathrm{Si}_{3} \mathrm{~N}_{4}\right)$ exit window, irradiates a sample located in ambient atmosphere $[8,9]$. The SPH setup is equipped with two detectors: a channeltron [10] and a silicon surface barrier particle detector [11]. A fast beam blanking system and proton detection system permit control of the number of protons hitting the target. Just prior to the irradiation of unstained cells, they are visualized on-line in transmitted light (LED diode located inside measurement chamber) via a microscope with a CCD camera. The 


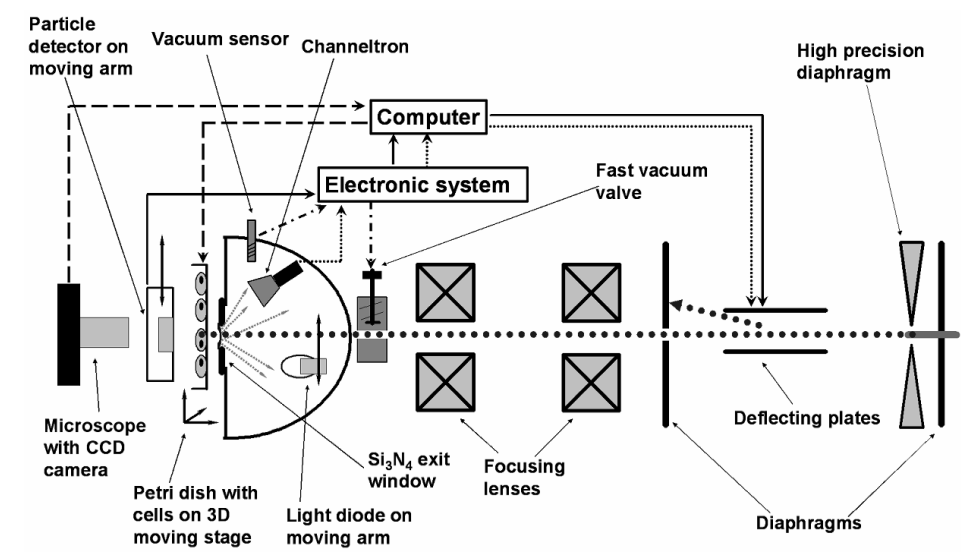

Fig. 1. Single proton hit setup in the IFJ PAN Kraków.

cell coordinates are transferred to the precise 2D (Physik Instrumente, Voice Coil type V-106 2S, resolution of $0.1 \mu \mathrm{m}$ ) moving table. The whole system is controlled with specialized computer software (Fig. 1).

\section{Optimizing measurements}

\subsection{External $\mu$-beam}

The resolution of the $\mu$-beam in air critically depends on a distance between a sample and an exit window. Protons passing through the window are scattered in the $\mathrm{Si}_{3} \mathrm{~N}_{4}$ window membrane. To estimate the resolution and accuracy of the

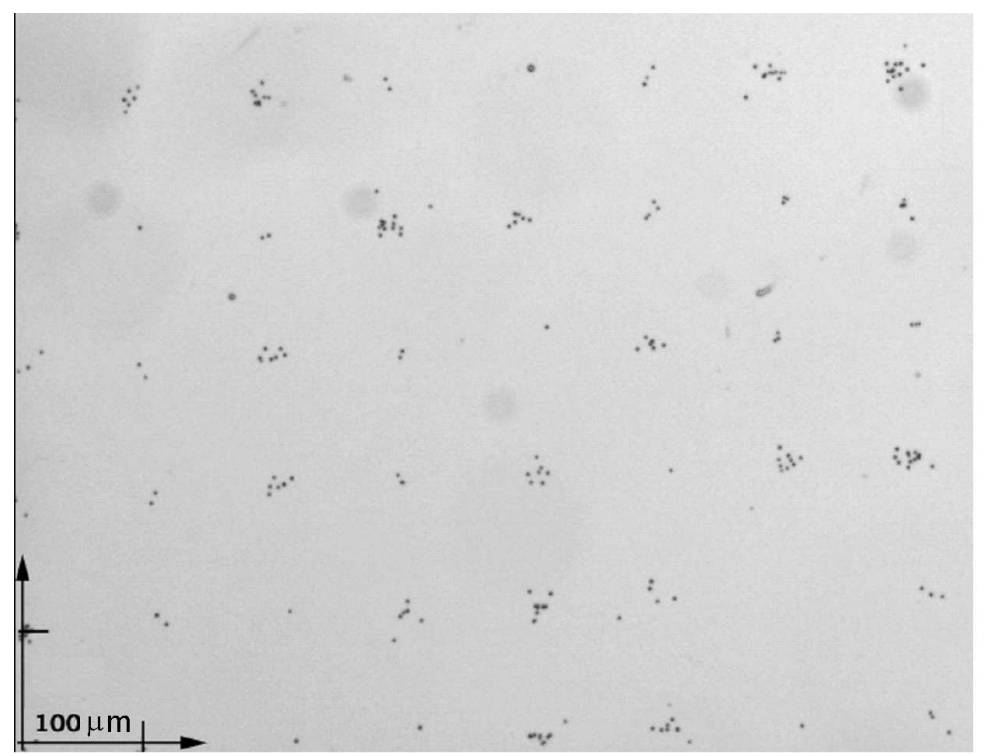

Fig. 2. Proton tracks visualized on CR-39 detector. 
SPH system we performed a scanning experiment where a solid state CR-39 [9] ion track detector (1.5 mm thick) was positioned on a 2D stage close behind the exit window $(\approx 200 \mu \mathrm{m})$. As a result $92 \%$ of proton tracks found on a CR-39 detector were located in required areas within $30 \mu \mathrm{m}$ diameter regions (Fig. 2).

\subsection{The proton registration and blanking system}

Two methods of proton registration are possible: the particle detector located behind the Petri dish with cells or a channeltron registering the secondary electrons emitted during proton passage through the exit window $[12,13]$. The first method allows $100 \%$ of protons registration efficiency (versus only $61 \%$ obtained for protons using channeltron). The drawback of this system is that the

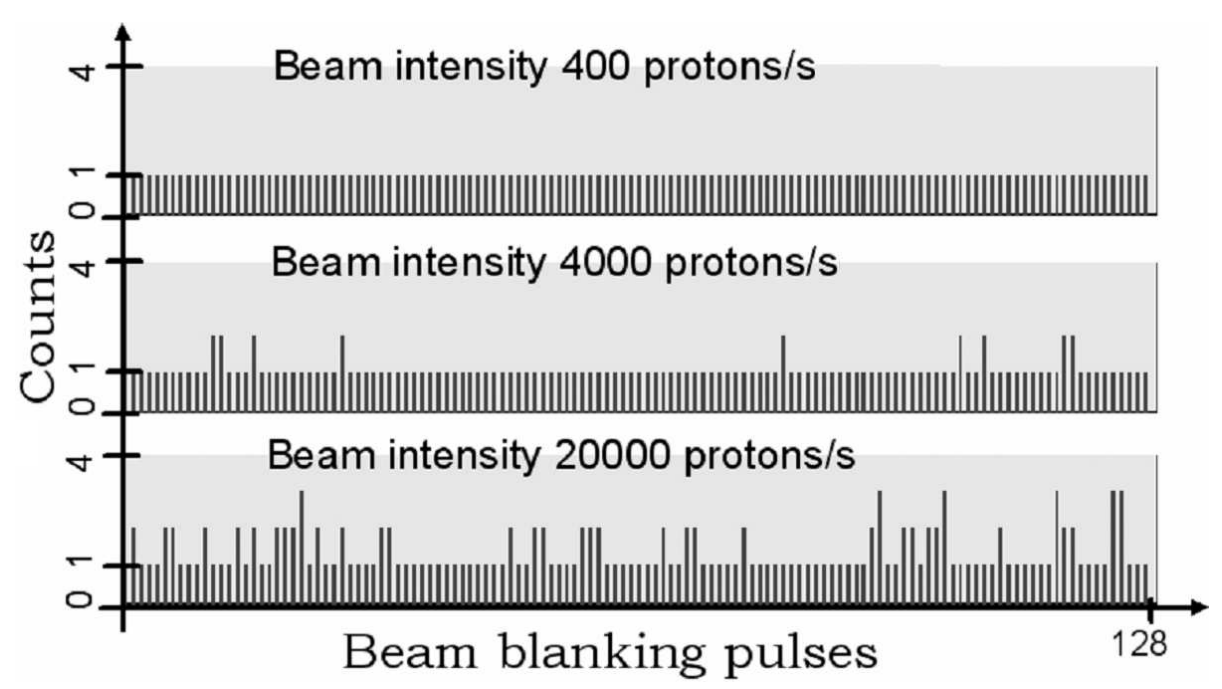

Fig. 3. Proton beam deflecting efficiency as a function of beam intensity for a registration system basing on the particle detector.

experiment time is limited to $\approx 10 \mathrm{~min}$ to guarantee cells survival, as prior to irradiation medium must be temporarily removed from a Petri dish. This could be avoided using the second method, but only after improvement of its currently unsatisfactory efficiency [13]. The blanking system with a silicon detector as a trigger, for the beam intensity of about 800 protons/s indicates $99.8 \%$ blanking efficiency (Fig. 3).

\section{Conclusions}

The first external microbeam in Poland has been successfully introduced. As a result of application of a silicon detector and the on-line observation system, the setup allows the irradiation of a single cell with a defined number of protons, with the hit accuracy of $30 \mu \mathrm{m}$. Using secondary electrons from the exit window as a proton-passing-through detector was tested, but curently it does not meet 
experimental requirements. All systems such as: proton detecting, blanking, cell recognition, positioning, are bound together and controlled with dedicated computer software. After a few years of development and construction the biological experiments have just started.

\section{Acknowledgments}

The authors acknowledge the help of Tomasz Horwacik for preparing and etching CR-39 detectors and the help of Roman Hajduk with taking care of electronic equipment. The study was partially supported by 6th Framework Programme grant CELLION No. MRTN-CT-2003-503923 and the Committee for Scientific Research (Poland) grant No. G02284.

\section{References}

[1] H. Zhou, M. Suzuki, G. Randers-Pehrson, D. Vannais, G. Chen, J.E. Trosko, C.A. Waldren, T.K. Hei, Proc. Nat. Acad. Sci. USA 98:25, 14410 (2001).

[2] M. Folkard, B. Vojnovic, K.M. Prise, A.G. Bowey, G. Schettino, B.D. Michael, Int. J. Radiat. Biol. 72, 375 (1997).

[3] P. Moretto, C. Michelet, A. Balana, P. Barberet, W.J. Przybylowicz, J.P. Slabbert, V.M. Prozesky, C.A. Pineda, G. Brut, G. Laurent, F. Lhoste, Nucl. Instrum. Methods Phys. Res. B 181, 104 (2001).

[4] M. Cholewa, M. Heiß, Nucl. Instrum. Methods Phys. Res. B 210, 296 (2003).

[5] H. Nagasawa, J.B. Little, Cancer Research 52, 6394 (1992).

[6] S. Lebed, J. Lekki, M. Paszkowski, W. Polak, A. Potempa, Z. Stachura, J. Styczeń, Problems of Atomic Science and Technology, Series "Nuclear Physics Investigations" 3, 71 (2001).

[7] J. Lekki, M. Cholewa, E. Dutkiewicz, A. Gwiazdowska, R. Hajduk, K. Irzyńska, S. Lebed, P. Mazur, W. Polak, A. Potempa, T. Pieprzyca, C. Sarnecki, Z. Szklarz, A. Veselov, R. Zając, Z. Stachura, J. Styczeń, IFJ Report No. 1915, 2002.

[8] http://www.silson.com.

[9] W. Polak, R. Hajduk, S. Lebed, J. Lekki, T. Horwacik, S. Maranda, T. Pieprzyca, C. Sarnecki, Z. Stachura, Z. Szklarz, O. Veselov, J. Styczeń, IFJ Report No. 1955/AP, 2004

[10] http://www.sjuts.com.

[11] http://www.ortec-online.com/detectors/chargedparticle/b_series.htm.

[12] W. Polak, J. Lekki, J. Gryboś, R. Hajduk, M. Cholewa, O. Kukharenko, Z. Stachura, Nukleonika 48, 25 (2003).

[13] M. Cholewa, T. Kamiya, A. Saint, S. Prawer, G. Legge, J.E. Butler, D.J. Vestyck, Diamond and Related Materials 7, 510 (1998). 